\title{
HHV8-positive, EBV-positive Hodgkin lymphoma-like large B-cell lymphoma and HHV8-positive intravascular large B-cell lymphoma
}

\author{
Judith A Ferry ${ }^{1}$, Aliyah R Sohani ${ }^{1}$, Janina A Longtine ${ }^{2}$, Robert A Schwartz ${ }^{3}$ and \\ Nancy L Harris ${ }^{1}$ \\ ${ }^{1}$ Department of Pathology, James Homer Wright Pathology Laboratories, Massachusetts General Hospital, \\ Boston, MA, USA; ${ }^{2}$ Department of Pathology, Brigham and Women's Hospital, Boston, MA, USA and \\ ${ }^{3}$ Department of Pathology, Manchester Memorial Hospital, Manchester, CT, USA
}

\begin{abstract}
Human herpesvirus type 8 (HHV8), also known as Kaposi's sarcoma-associated herpesvirus, is a human $\gamma$ herpesvirus that underlies the pathogenesis of Kaposi's sarcoma, primary effusion lymphoma and multicentric Castleman's disease. We recently encountered two cases of HHV8-positive large B-cell lymphoma with features not previously described. The first patient was a 61-year-old immunocompetent man with an enlarged cervical lymph node containing scattered large, bizarre cells in a reactive background of lymphocytes, plasma cells and scattered regressed follicles resembling those of hyaline-vascular Castleman's disease. The appearance suggested classical Hodgkin's lymphoma, but the large cells were negative for CD15, CD30, CD20 and CD3, and positive for MUM1/IRF4, EMA, HHV8, EBER and $\operatorname{dim} \operatorname{IgM} \lambda$. The second patient was a 59-year-old HIV-positive man who died after several weeks of fever, night sweats, anemia, thrombocytopenia, hepatosplenomegaly and multiorgan failure. At autopsy an intravascular large B-cell lymphoma that was positive for MUM1/IRF4, HHV8 and $\lg M \lambda$, and negative for CD20 and EBER involved multiple organs, including lung, heart, kidney, liver and spleen. On the basis of the histologic features in these two cases, the presence of HHV8 was unexpected. These cases expand the spectrum of lymphoproliferative disorders that can be associated with HHV8. Modern Pathology (2009) 22, 618-626; doi:10.1038/modpathol.2009.36; published online 13 March 2009
\end{abstract}

Keywords: HHV8; KSHV; HIV; lymphoma; intravascular lymphoma

Human herpesvirus type 8 (HHV8), also known as Kaposi's sarcoma-associated herpesvirus (KSHV), was first identified as the causative agent of Kaposi's sarcoma in $1994 .{ }^{1}$ Subsequently HHV8 was identified in primary effusion lymphoma, ${ }^{2}$ in a majority of cases of multicentric Castleman's disease, ${ }^{3,4}$ in the plasmablastic proliferations that arise in the setting of multicentric Castleman's disease ${ }^{4}$ and in the rare entity known as germinotropic lymphoproliferative disorder. ${ }^{5}$ Except for germinotropic lymphoproliferative disorder the majority of these disorders arise in HIV-positive patients. ${ }^{2,3,6}$ We report two cases of HHV8-positive lymphoproliferative disorders with

Correspondence: Dr JA Ferry, MD, Department of Pathology, Massachusetts General Hospital, Fruit Street, Boston, MA 02114, USA.

E-mail: jferry@partners.org

Received 3 January 2009; revised 18 February 2009; accepted 20 February 2009; published online 13 March 2009 pathologic features not previously described. One case occurred in an immunocompetent adult male and had histologic, but not immunophenotypic, features reminiscent of classical Hodgkin's lymphoma, and concurrent infection of neoplastic cells by HHV8 and Epstein-Barr virus (EBV). The second case was an HHV8-positive intravascular large B-cell lymphoma diagnosed at autopsy in an HIV-positive man.

\section{Case Histories}

\section{Case 1}

The patient was a 61-year-old man with a history of hypertension and heavy alcohol use with possible cirrhosis, but who was otherwise well with no known immunodeficiency until he suffered a ruptured berry aneurysm. He became comatose and remained unconscious, on a ventilator for 5 weeks. 
Remarkably he recovered, with his only deficit being mild hearing loss, possibly related to aminoglycoside antibiotic therapy. During evaluation by an otolaryngologist, cervical and supraclavicular lymphadenopathy was identified. A left deep cervical lymph node was excised. Serologic studies revealed no evidence of HIV infection. Staging revealed PET-avid cervical, supraclavicular, paratracheal and mediastinal lymphadenopathy. Bone marrow examination was negative for involvement by lymphoma. Ann Arbor stage was IIa. Six cycles of cyclophosphamide, doxorubicin, vincristine and prednisone with rituximab (R-CHOP) were administered. The patient achieved complete remission and is well, with no evidence of lymphoma, 10 months after diagnosis (Table 1).

\section{Case 2}

The patient was a 59-year-old Filipino man who presented with fever and night sweats, 3 months after being found to be HIV positive. On admission he was anemic and thrombocytopenic. A bone marrow biopsy showed mild trilineage dysplasia attributed to the patient's HIV status. Work-up for infectious disease, including blood cultures, mycobacterial culture and serologic studies for cytomegalovirus and fungi, was negative. The patient received antibiotics for atypical mycobacterial infection and for other possible occult infections with apparent improvement, and was discharged. Over the next 3 weeks substernal chest pain, a diffuse pruritic rash on his torso, high fevers, weakness and epigastric pain developed. On readmission to the hospital, physical examination revealed hepatosplenomegaly. The patient was treated with broadspectrum antibiotics and anti-retroviral therapy without improvement. Hypotension, acute renal failure and metabolic acidosis developed and he expired on the eighth hospital day, 27 days after his first hospital admission. An autopsy was performed (Table 1).

\section{Materials and methods}

Hematoxylin and eosin stained sections of the cervical lymph node in Case 1 and of tissue sampled at autopsy in Case 2 were submitted in consultation to two of the authors (JAF and NLH). Special stains for microorganisms were also examined in Case 2. Immunostains submitted for review were also examined. In Case 1, these were CD45, CD20, CD3 (all prediluted; Vision Biosystems/Novocastra, New Castle Upon Tyne, UK), Pax5 (1:60; Vision Biosystems/Novocastra), CD15 (1:20; Vision Biosystems/ Novocastra) and CD30 (1:40; Vision Biosystems/ Novocastra), performed on the Bond Max Immunostainer, and EMA (1:200; Dako, Carpinteria, CA, USA), performed on the Dako Autostainer Plus. In Case 2, these included CD45, CD20, CD30 and CD34, all prediluted, supplied by Ventana and performed on the Ventana Benchmark autostainer using UltraView DAB chromogen (Ventana Medical Systems Inc., Tucson, AZ, USA). Also reviewed were immunostains for CD56 (1:200; Lab Vision) and CD79a (1:500; Dako), performed on the Leica-Microsystems Bond Max instrument.

Additional immunohistochemical analyses were performed at the Massachusetts General Hospital on the Ventana Benchmark autostainer on 2- $\mu$ m-thick formalin-fixed, paraffin-embedded sections from the cervical lymph node in Case 1, and on selected tissues obtained at autopsy in Case 2 using the Ventana 3,3'-diaminobenzidine tetrahydrochloride kit according to the manufacturer's instructions. Stains were performed on one or both cases with antibodies to the following: CD45 (prediluted; Ventana), CD20 (prediluted; Ventana), CD79a (prediluted; Ventana), Pax5 (prediluted; Ventana), MUM1/IRF4 (1:20; Dako), CD138 (1:30; Serotec, Raleigh, NC, USA), HHV8 (1:50; Advanced Biotechnologies, Columbia, MD, USA), $\mu$ heavy chain (1:700; Dako), $\gamma$ heavy chain (1:800; Dako), $\alpha$ heavy chain (1:600; Dako), CD2 (1:50; Novocastra), CD5 (prediluted; Ventana), CD7 (prediluted; Dako), CD4 (1:20; Novocastra), CD8 (prediluted; Ventana), CD30 (prediluted; Ventana), ALK (prediluted; Ventana), CD117 (1:2; Cell Marque, Rocklin, CA, USA), MPO (1:700; Dako), CD68 (prediluted; Ventana) and cytokeratin cocktail (CAM5.2, 1:80; Becton Dickinson, San Jose, CA, USA; AE1 and AE3, 1:160; Signet Laboratories, Dedham, MA, USA) were used. Expression of immunoglobulin light chains $\kappa$ and $\lambda$ and presence of EBV were assessed by in situ hybridization using the Ventana ISH iView kit with probes for $\kappa, \lambda$ and EBER.

In Case 1, tissue for polymerase chain reaction (PCR) was obtained by gross microdissection using a scalpel on $5-\mu \mathrm{m}$ sections of paraffin-embedded tissue on glass slides, choosing only areas with greater concentration of large cells for analysis. In Case 2, paraffin-embedded lung tissue was used. In both cases, DNA was analyzed by a PCR technique using primers conjugated with fluorescent dyes that hybridize to conserved framework (regions 1, 2 and 3) and joining regions of the immunoglobulin heavy chain gene (IGH) (InVivoScribe Technologies, BIOMED, San Diego, CA, USA). In Case 2, DNA was also isolated and analyzed by a PCR technique using primers conjugated with fluorescent dyes that hybridize to T-cell receptor gamma chain $(T C R \gamma)$ gene $\mathrm{V}$ segment 1-8, 9, 10, $11(\mathrm{~V} \gamma 1-8, \mathrm{~V} \gamma 9, \mathrm{~V} \gamma 10, \mathrm{~V} \gamma 11)$ and joining region ( $\mathrm{J} \gamma 1$ and $\mathrm{J} \gamma 2$ ) (InVivoScribe Technologies, BIOMED). The DNA was also amplified with control primers to multiple gene segments $(64-600 \mathrm{bp}$ in length) to assess the integrity and quality of the isolated DNA. The PCR products were analyzed by capillary gel electrophoresis. Approval for this study was obtained from the Partners Institutional Review Board. 
Table 1 HHV8-positive lymphoproliferative disorders: clinical features

\begin{tabular}{|c|c|c|c|c|c|c|c|}
\hline Features & Case 1 & Case 2 & PEL & $\begin{array}{l}\text { Solid lymphomas, } \\
\text { PEL-like }\end{array}$ & $M C D$ & $\begin{array}{l}\text { MCD-associated } \\
\text { plasmablastic } \\
\text { proliferations }\end{array}$ & $\begin{array}{l}\text { Germinotropic } \\
\text { lymphoproliferative } \\
\text { disorder }\end{array}$ \\
\hline $\begin{array}{l}\text { Synonym(s) and } \\
\text { related terms }\end{array}$ & - & - & $\begin{array}{l}\text { Body cavity-based } \\
\text { lymphoma }\end{array}$ & $\begin{array}{l}\text { Extracavitary PEL, } \\
\text { IBL/PBL DLBCL }\end{array}$ & $\begin{array}{l}\text { PBL Castleman's } \\
\text { disease }\end{array}$ & $\begin{array}{l}\text { PBL microlymphoma, } \\
\text { Frank PBL lymphoma, } \\
\text { LBCL arising in } \\
\text { HHV8-associated } \\
\text { MCD }\end{array}$ & - \\
\hline Presenting symptoms & $\begin{array}{l}\text { Asymptomatic } \\
\text { lymphadenopathy }\end{array}$ & $\begin{array}{l}\text { Fever, night sweats, } \\
\text { anemia, } \\
\text { thrombocytopenia }\end{array}$ & $\begin{array}{l}\text { Dyspnea or } \\
\text { abdominal } \\
\text { distension }\end{array}$ & $\begin{array}{l}\text { Fever, night sweats } \\
\text { and/or weight loss }\end{array}$ & $\begin{array}{l}\text { Constitutional } \\
\text { symptoms, } \\
\text { cytopenias }\end{array}$ & $\begin{array}{l}\text { Constitutional } \\
\text { symptoms, cytopenias }\end{array}$ & Lymphadenopathy \\
\hline $\begin{array}{l}\text { Anatomic sites } \\
\text { involved }\end{array}$ & $\begin{array}{l}\text { Lymph nodes (Ann } \\
\text { Arbor stage II) }\end{array}$ & $\begin{array}{l}\text { Lungs, liver, } \\
\text { spleen, kidney, } \\
\text { heart, lymph node }\end{array}$ & $\begin{array}{l}\text { Pleural, pericardial } \\
\text { or peritoneal cavity }\end{array}$ & $\begin{array}{l}\text { GI tract, skin, soft } \\
\text { tissue, lung, } \\
\text { spleen, lymph } \\
\text { nodes }\end{array}$ & $\begin{array}{l}\text { Multiple lymph } \\
\text { nodes, spleen }\end{array}$ & $\begin{array}{l}\text { Multiple lymph } \\
\text { nodes, spleen }\end{array}$ & $\begin{array}{l}\text { Localized or } \\
\text { multifocal lymph } \\
\text { nodal involvement }\end{array}$ \\
\hline Age, Gender & $62, \mathrm{M}$ & $59, \mathrm{M}$ & $\begin{array}{l}\text { HIV+: young to } \\
\text { middle aged, } M \gg F \text {; } \\
\text { HIV-: mostly } \\
\text { elderly, } M \text { and } F\end{array}$ & $\begin{array}{l}\text { HIV+: young to } \\
\text { middle aged, M } \gg \text { F; } \\
\text { HIV-: elderly }\end{array}$ & $\begin{array}{l}\text { HIV+: young to } \\
\text { middle-aged } \\
\text { adults, M } \gg \text { F; } \\
\text { HIV-: adults, } \\
\mathrm{M}=\mathrm{F}\end{array}$ & $\begin{array}{l}\text { Young to middle-aged } \\
\text { adults, } M \gg F\end{array}$ & $41, \mathrm{M} ; 61, \mathrm{M} ; 63, \mathrm{~F}$ \\
\hline HIV status & - & + & Most+, few- & Most+, few- & $+1-$ & $++/-$ & - \\
\hline Outcome & NED, 10 months & $\begin{array}{l}\text { Died of lymphoma, } \\
1 \text { month }\end{array}$ & Very poor & $\begin{array}{l}\text { Poor; some patients } \\
\text { develop } \\
\text { lymphomatous } \\
\text { effusions }\end{array}$ & Poor & Poor & Good \\
\hline
\end{tabular}

PEL, primary effusion lymphoma; MCD, multicentric Castleman's disease; IBL, immunoblastic; PBL, plasmablastic; DLBCL, diffuse large B-cell lymphoma; LBCL, large B-cell lymphoma; M, male; $\mathrm{F}$, female; NED, no evidence of disease. 


\section{Results}

\section{Case 1}

Microscopic examination revealed an enlarged lymph node with widely scattered follicles with an appearance reminiscent of those seen in hyalinevascular Castleman's disease. There were scattered interfollicular large, bizarre cells with oval, indented or ring-shaped nuclei, prominent nucleoli and abundant cytoplasm, in a background of small lymphocytes and occasional plasma cells. Some large cells were apoptotic, resembling the mummified cells of Hodgkin's lymphoma. Rare large cells closely resembling Reed-Sternberg cells were identified (Figure 1a-c).

Flow cytometric analysis performed at the original hospital showed polytypic B cells and T cells with an elevated CD4/CD8 ratio. Immunostains performed previously and submitted for review showed that large bizarre cells were positive for CD45(dim) and for EMA, and negative for CD15, CD30, CD20 and Pax5. Immunostains prepared in our laboratory showed that large cells were positive for MUM1/ IRF4 and CD138(dim), and negative for CD3, Alk and cytokeratin. With antibody to HHV8, the nuclei of large cells were bright positive. In situ hybridization for EBV (EBER probe) showed staining in the same pattern as HHV8. In situ hybridization for $\kappa$ and $\lambda$ immunoglobulin light chain showed that large cells were dim monotypic $\lambda$ light chain positive, with coexpression of $\mu$ heavy chain (Figure $1 \mathrm{~d}-\mathrm{j}$; Table 2). Small cells in the interfollicular area were a mixture of T cells (CD3 positive; CD4 > CD8) and B cells (CD20 and Pax5 positive). Plasma cells were polytypic. Results of PCR were polyclonal for $I G H$ rearrangements, although because of the many admixed small cells, the possibility of a falsenegative result could not be excluded. A diagnosis of HHV8-positive, EBV-positive large B-cell lymphoma with monotypic IgM $\lambda$ expression was made.
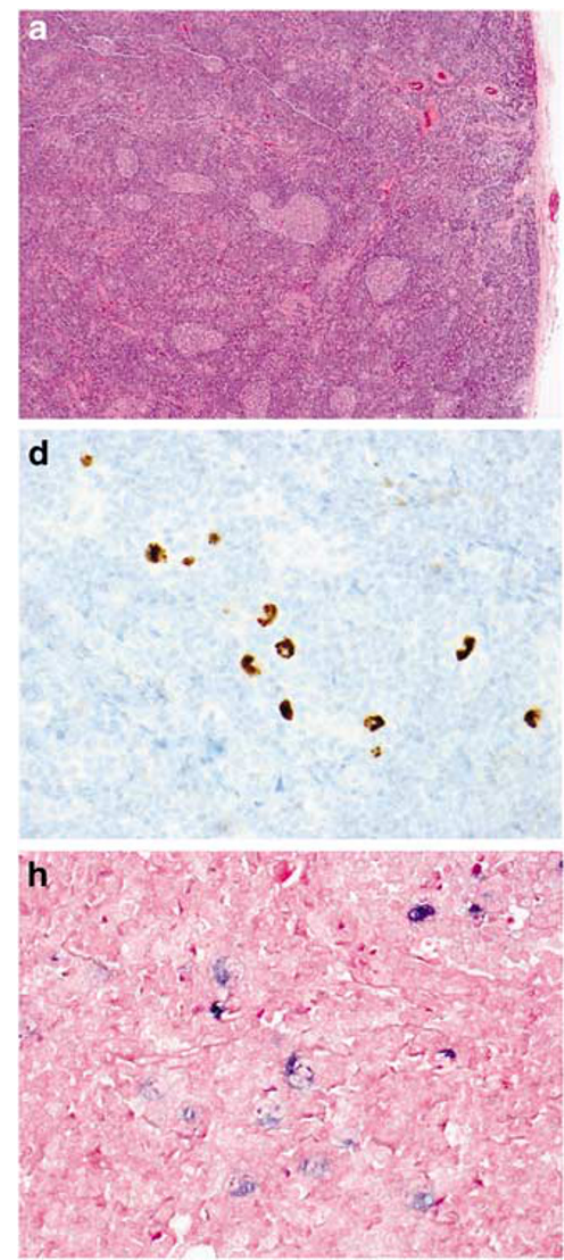
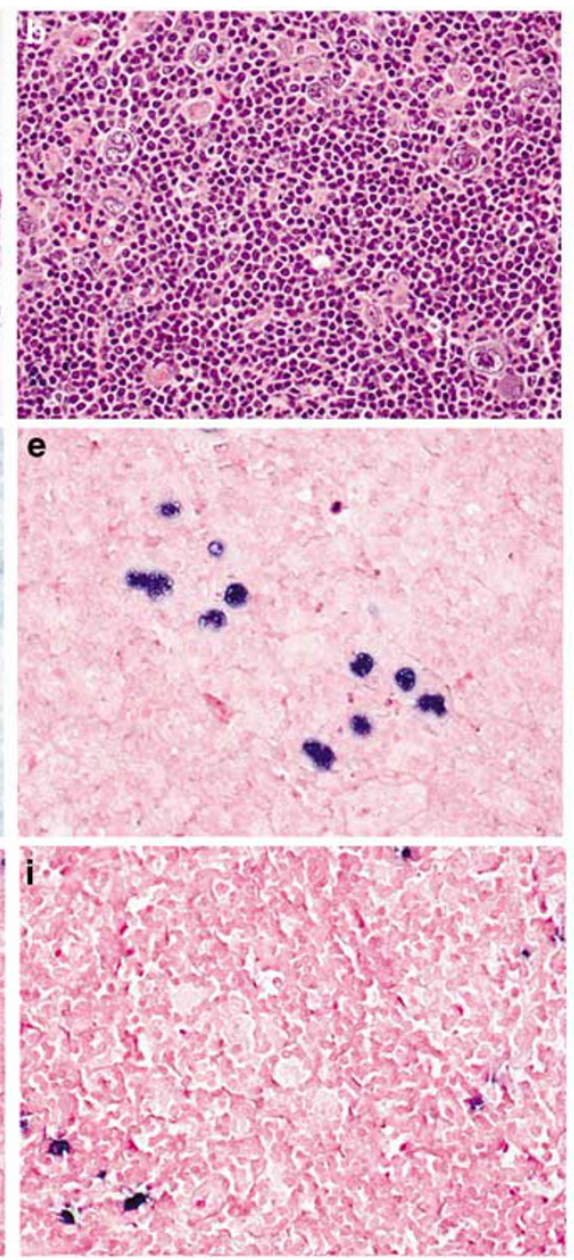
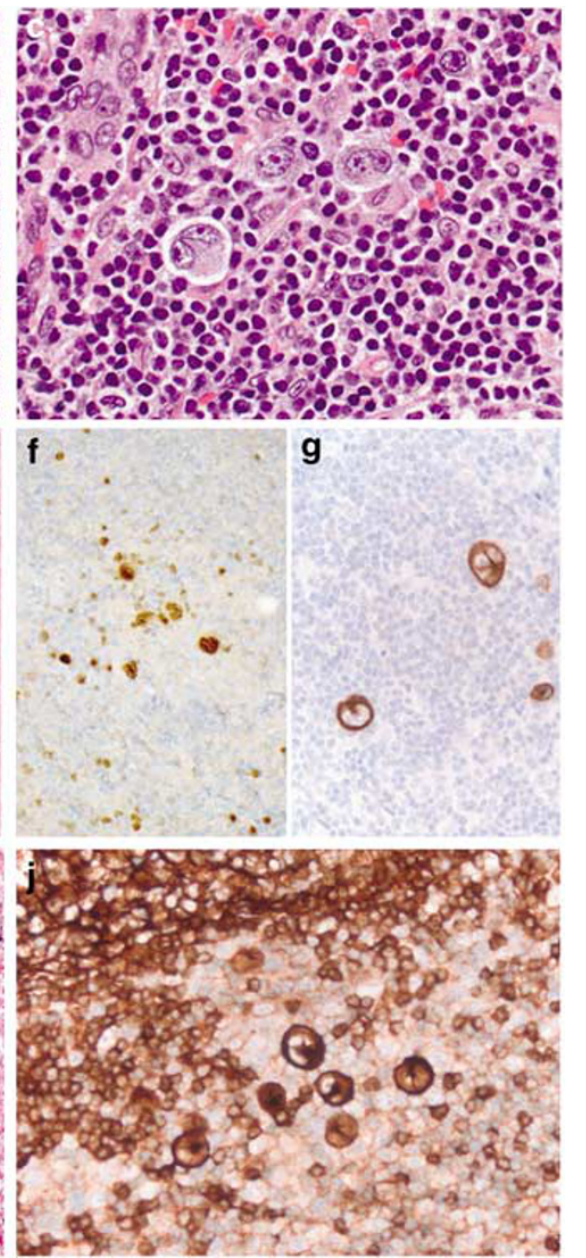

Figure 1 Case 1, cervical lymph node. (a) Low power shows a lymph node with evenly placed, reactive-appearing follicles. Some are small and inactive, reminiscent of those seen in Castleman's disease. (b) High power shows large atypical cells with deeply indented or lobated nuclei, vesicular chromatin and red nucleoli in a background of small lymphocytes. (c) Binucleated large cells reminiscent of Reed-Sternberg cells are present. (d-g) Large atypical cells are positive for HHV8 (d), Epstein-Barr virus (EBER probe) (e) (d and e illustrate similar high-power fields), MUM1/IRF4 (f) and EMA (g). (h-j) Large atypical cells express dim $\lambda$ light chain (h) but not $\kappa$ light chain (i). Plasma cells are polytypic. Large cells coexpress $\mu$ heavy chain; follicles are also stained (j). (d, f, g and j: immunoperoxidase technique on paraffin sections; $\mathbf{e}, \mathbf{h}$ and $\mathbf{i}$ : in situ hybridization on paraffin sections). 
Table 2 HHV8-positive lymphoproliferative disorders: pathologic features

\begin{tabular}{|c|c|c|c|c|c|c|c|}
\hline Features & Case 1 & Case 2 & $P E L$ & $\begin{array}{l}\text { Solid lymphomas, } \\
\text { PEL-like }\end{array}$ & $M C D$ & $\begin{array}{l}\text { MCD-associated } \\
\text { plasmablastic } \\
\text { proliferations }\end{array}$ & $\begin{array}{l}\text { Germinotropic } \\
\text { lymphoproliferative } \\
\text { disorder }\end{array}$ \\
\hline Microscopic features & $\begin{array}{l}\text { Interfollicular large } \\
\text { bizarre cells in } \\
\text { reactive } \\
\text { background; } \\
\text { regressed follicles, } \\
\text { HVCD-like }\end{array}$ & $\begin{array}{l}\text { Large intravascular } \\
\text { cells c/w } \\
\text { immunoblasts or } \\
\text { plasmablasts }\end{array}$ & $\begin{array}{l}\text { Large, bizarre, } \\
\text { pleomorphic or } \\
\text { immunoblast-like } \\
\text { cells dispersed in } \\
\text { fluid }\end{array}$ & $\begin{array}{l}\text { Large } \\
\text { immunoblast-like } \\
\text { or pleomorphic } \\
\text { bizarre cells }\end{array}$ & $\begin{array}{l}\text { Plasmablasts in } \\
\text { follicle mantles; } \\
\text { CD-like changes }\end{array}$ & $\begin{array}{l}\text { Aggregates or sheets of } \\
\text { plasmablasts; CD-like } \\
\text { changes }\end{array}$ & $\begin{array}{l}\text { Plasmablasts, some } \\
\text { bizarre cells } \\
\text { replacing follicles }\end{array}$ \\
\hline CD45 & Dim+ & + & + & $+1-$ & NA & NA & NA \\
\hline CD20 & - & - & - & $-1+$ & $+1-$ & $+1-$ & - \\
\hline MUM1/IRF4 & + & + & + & + & NA & + & NA \\
\hline CD138 & Dim+ & - & $+1-$ & $+1-$ & N/A & - & - \\
\hline $\operatorname{Ig}$ & $\operatorname{IgM} \lambda \operatorname{dim}+$ & $\operatorname{IgM} \lambda+$ & - & $-/+(\lambda \gg \kappa)$ & $\operatorname{IgM} \lambda$ & $\operatorname{IgM} \lambda$ & $\begin{array}{l}\text { Ig+, } \kappa \text { or } \lambda \text {, any } \\
\text { heavy chain }\end{array}$ \\
\hline CD30 & - & - & + & $+1-$ & - & NA & + or - \\
\hline EBV & + & - & $++/-$ & $++/-$ & - & - & + \\
\hline$I G H$ & $\begin{array}{l}\text { Polyclonal (false } \\
\text { negative due to few } \\
\text { abnormal cells?) }\end{array}$ & Clonal & Clonal & Clonal & Polyclonal & Polyclonal or Clonal & $\begin{array}{l}\text { Polyclonal or } \\
\text { oligoclonal }\end{array}$ \\
\hline Other genetic features & ND & ND & $\begin{array}{l}I G H \text { and } B C L 6 \\
\text { mutated in most } \\
\text { cases; no } \\
\text { translocations of } \\
B C L 1, B C L 2, B C L 6 \\
\text { or } M Y C\end{array}$ & $\begin{array}{l}\text { No translocations } \\
\text { of } B C L 1, B C L 2 \text {, } \\
B C L 6 \text { or } M Y C\end{array}$ & IGH unmutated & IGH unmutated & $I G H$ mutated \\
\hline
\end{tabular}




\section{Case 2}

External examination at autopsy revealed cutaneous jaundice and scleral icterus. The left and right pleural, pericardial and peritoneal cavities all contained serous fluid $(350,400,60$ and $800 \mathrm{cc}$, respectively). Pleural, pericardial and peritoneal surfaces were smooth and free of adhesions. The heart was enlarged (650 g). The lungs showed diffuse emphysematous change and bilateral lower lobe congestion, but no focal lesions. The liver $(3500 \mathrm{~g})$ and spleen $(1620 \mathrm{~g})$ were markedly enlarged, but were free of mass lesions.

Microscopic examination of sections taken from the heart, lungs, kidneys, liver and spleen showed multifocal intravascular collections of large lymphoid cells with prominent central nucleoli and moderately abundant amphophilic cytoplasm. No extravascular infiltrates were identified. In the lung, the large cells were present in alveolar capillaries as well as in small blood vessels around bronchi. They were focally present within vessels in the heart and involved numerous blood vessels in the kidney as well as the sinuses of the spleen (Figure 2a-c). One small anthracotic lymph node included in a section with lung contained large atypical lymphoid cells in blood vessels as well as in sinuses. Blood vessels in perinodal fat also contained large lymphoid cells. Pleural, pericardial and peritoneal surfaces were free of atypical cells. The atypical cells were positive for CD45, CD79a (focal, dim), MUM1/ IRF4, with dim expression of CD4 but showed no definite expression of CD20, CD30, CD34, CD56, CD138, CD2, CD5, CD7, CD8, CD117, myeloperoxidase or CD68. In situ hybridization for $\kappa$ and $\lambda$ light chains and immunoperoxidase staining for $\gamma, \mu$ and $\alpha$ heavy chains showed monotypic IgM $\lambda$ expression by the atypical cells. Rare small lymphoid cells within the lymph node were positive for EBV (EBER probe), but tumor cells were negative. The tumor cells were uniformly and strongly positive for HHV8 (Figure 2d; Table 2). No microorganisms were identified on special stains for acid-fast bacilli and fungi on sections of lung, liver and spleen. Flow

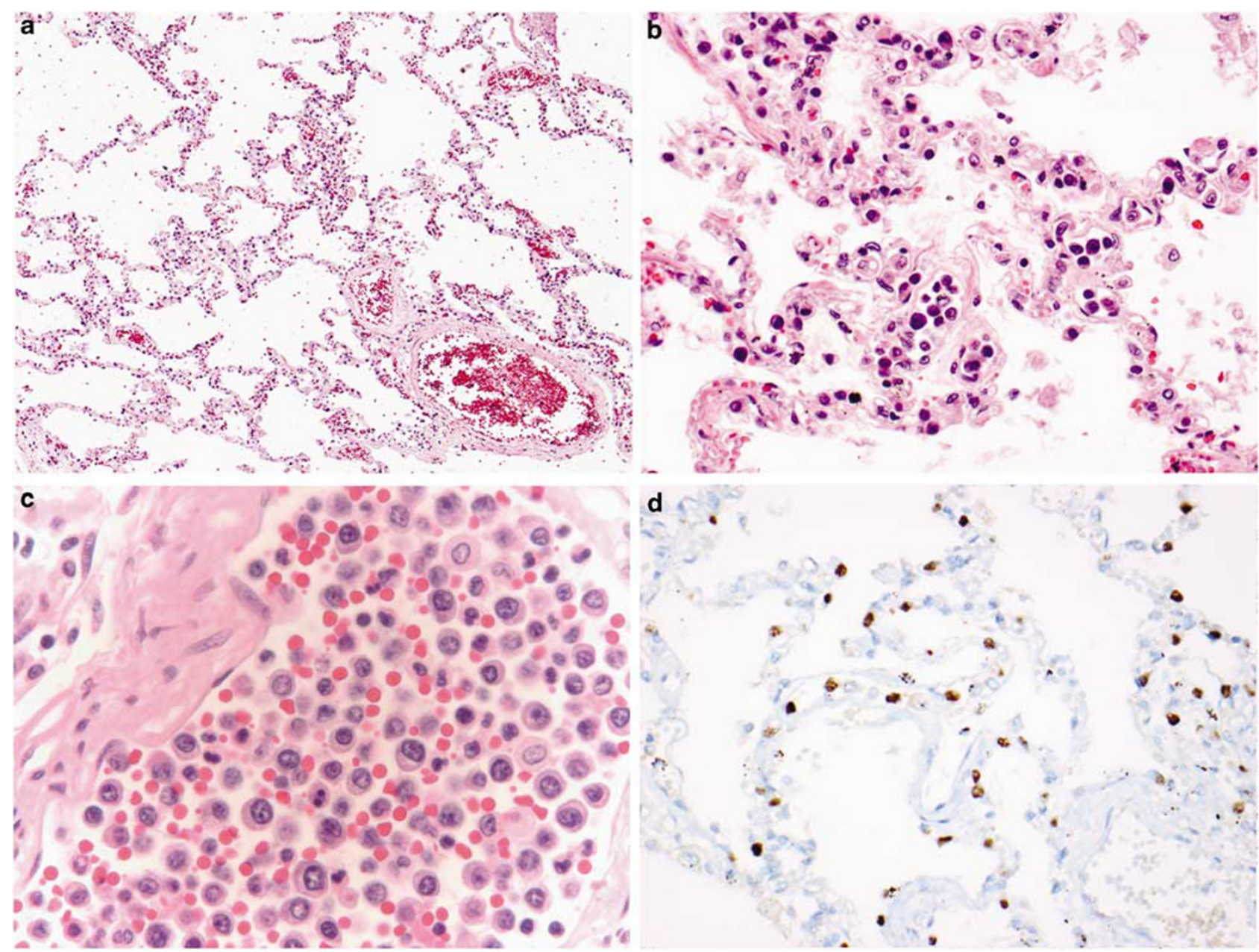

Figure 2 Case 2. (a) Low-power examination of lung shows increased cellularity in alveolar walls. (b) High power shows large atypical lymphoid cells in alveolar capillaries. (c) High power of a larger blood vessel shows numerous large lymphoid cells with plasmacytoid features. (d) The large lymphoid cells are HHV8 positive (immunoperoxidase technique on a paraffin section). 
cytometric analysis performed at the original hospital on liver, spleen and lymph node was technically suboptimal due to poor specimen viability.

Molecular genetic analysis of tissue from the lung by PCR showed inadequate DNA amplification to evaluate the larger $I G H$ framework I rearrangements. Both framework II and III amplifications showed a dominant peak within a polyclonal background. There was minimal amplification with TCR $\gamma$ primers in a polyclonal pattern; DNA fragments up to 190 in length amplified with the control primers. The expected size range for $T C R \gamma$ rearrangements is 80-225 bp. The findings were consistent with a dominant B-cell clone within a polyclonal background. The findings were interpreted as an HHV8-positive intravascular large B-cell lymphoma.

\section{Discussion}

HHV8 is associated with three main categories of disease: Kaposi's sarcoma, ${ }^{1}$ primary effusion lymphoma $^{2}$ and multicentric Castleman's disease and the plasmablastic proliferations that arise from it. ${ }^{4,6}$ Primary effusion lymphoma is a distinctive type of diffuse large $B$ cell initially recognized in HIVpositive patients, characterized by occurrence in a body cavity unassociated with a contiguous solid mass, immunophenotypic and genetic features corresponding to a late postgerminal center B cell in most cases, ${ }^{2,7-12}$ a distinctive gene expression profile $^{13,14}$ and a poor prognosis. ${ }^{2,7,8,12,15}$ Tumor cells are usually coinfected by EBV, a $\gamma$ herpesvirus closely related to HHV8 (Tables 1 and 2). Nearly all cases of multicentric Castleman's disease in HIVpositive patients and a subset of multicentric Castleman's disease in HIV-negative individuals contain HHV8. ${ }^{3}$ Immunostains reveal that HHV8 is localized to plasmablasts scattered in expanded follicle mantles (plasmablastic Castleman's disease). ${ }^{4}$ In some cases, plasmablasts proliferate to replace whole follicles (plasmablastic microlymphoma) or grow diffusely (frank plasmablastic lymphoma). ${ }^{4,6}$ In the WHO classification, those plasmablastic proliferations that are monoclonal, including the frank plasmablastic lymphomas and a subset of the microlymphomas, are called large B-cell lymphoma arising in HHV8-associated multicentric Castleman's disease (Tables 1 and 2). ${ }^{16}$

Almost as soon as these associations were established, additional cases of HHV8-associated lymphoproliferative disorders were identified that deviated from the patterns already recognized. Although primary effusion lymphoma was initially described in the setting of HIV infection, it has been reported in an iatrogenically immunosuppressed cardiac transplant recipient ${ }^{17}$ and a number of cases have been found in HIV-negative patients without a specific immunodeficiency syndrome ${ }^{11,18-20}$ who sometimes also had Kaposi's sarcoma. ${ }^{19}$ HIV-negative individuals with primary effusion lymphoma tend to be elderly; ${ }^{11,18,19}$ it is possible that their advanced age represents a source of immunodeficiency. Certain other differences, such as occasional expression of B-cell markers ${ }^{18,19}$ and absence of EBV, are more frequent in primary effusion lymphomas in HIV-negative patients than in HIV-positive patients. ${ }^{19}$ In addition, site of disease proved to be somewhat variable: involvement of the subarachnoid space has been described, so that primary effusion lymphoma may arise in spaces lacking a mesothelial lining. ${ }^{8}$ In one remarkable case, a woman developed primary effusion lymphoma in an artificial cavity that had formed adjacent to the capsule of silicone breast implant, ${ }^{19}$ demonstrating that the body cavity giving rise to primary effusion lymphoma does not even have to be a normal anatomic structure.

Cases of HHV8-positive lymphoma with morphology and immunophenotype similar to those of primary effusion lymphoma but producing mass lesions in lymph nodes or in extranodal sites have also been described. ${ }^{8,16,20,21}$ These have been called HHV8-positive or KSHV-positive solid lymphomas or extracavitary primary effusion lymphomas, ${ }^{8,20}$ or KSHV-positive solid immunoblastic/plasmablastic diffuse large B-cell lymphomas. ${ }^{22}$ These 'solid lymphomas' show genetic features similar to those of primary effusion lymphoma, further supporting a close relationship between these two lymphomas..$^{8,9,20}$

Variations on the spectrum of changes associated with multicentric Castleman's disease have also been observed. Germinotropic lymphoproliferative disorder has histologic features similar to those of plasmablastic microlymphoma (Tables 1 and 2) but in contrast to multicentric Castleman's disease and its associated plasmablastic proliferations, germinotropic lymphoproliferative disorder affects HIV-negative individuals who present with lymphadenopathy without systemic symptoms and have a good outcome; HHV8-positive cells are coinfected by EBV. ${ }^{5}$ We have reported a case of plasmablastic microlymphoma arising in association with multicentric Castleman's disease in an HIV-positive man with concurrent infection of plasmablasts by EBV and HHV8; ${ }^{23}$ infection of B cells by both HHV8 and EBV is the typical finding in primary effusion lymphoma in HIV-positive patients and in germinotropic lymphoproliferative disorder, but it had not been previously described in multicentric Castleman's disease.

We now describe two B-lineage lymphomas with features not previously observed in association with HHV8. Our cases share a postgerminal center immunophenotype, with large atypical cells that were CD20 negative. Both expressed monotypic $\operatorname{IgM} \lambda$, showing the marked preferential $\lambda$ expression seen in HHV8-positive multicentric Castleman's disease and in the subset of HHV8-positive solid lymphomas that do express immunoglobulin light chain. They differed, however, with respect to 
clinical setting, anatomic distribution of disease, cytologic features of the HHV8-positive neoplastic cells, association with EBV and outcome (Tables 1 and 2). In Case 1, the presence of large bizarre cells, including some reminiscent of Reed-Sternberg cells, in a reactive background initially raised the question of interfollicular Hodgkin's lymphoma. The appearance of occasional large cells suggested the hallmark cells of anaplastic large-cell lymphoma. However, results of immunostains performed initially (CD45dim positive, CD15 negative, CD30 negative, EMA positive) excluded both classical Hodgkin's lymphoma and anaplastic large-cell lymphoma. The peculiar degenerated appearance of some of the large atypical cells provided a clue to the presence of viral alteration. The follicles were small, with morphology reminiscent of Castleman's disease, which may be seen in Hodgkin's lymphoma ${ }^{24}$ but which may also suggest the possibility of the presence of HHV8. Hodgkin's lymphoma is consistently negative for HHV8, even in cases in which patients are HIV positive and in which ReedSternberg cells are EBV positive, and even in the rare instance in which there is concurrent Kaposi's sarcoma. ${ }^{25}$ HHV8-positive plasmablastic Castleman's disease was a consideration, but the large, bizarre HHV8-positive cells did not resemble plasmablasts, and they did not preferentially reside in the follicle mantles. In contrast to plasmablastic microlymphoma, including our unusual HHV8positive, EBV-positive case noted above,$^{23}$ in which the HHV8-infected cells fill and replace the lymphoid follicle, in the current case the HHV8-positive cells were predominantly interfollicular. This case demonstrates that rarely HHV8 can produce a lymph node-based lymphoproliferative disorder in an immunocompetent host that may potentially mimic Hodgkin's lymphoma. Our case is difficult to subclassify. Perhaps it is most akin to early lymph nodal involvement by an HHV8-positive solid lymphoma. In contrast to most patients with HHV8-positive lymphoproliferative disorders, our patient was immunocompetent and asymptomatic, and his lymphadenopathy was essentially an incidental finding. His clinical presentation and favorable outcome are more reminiscent of germinotropic lymphoproliferative disorder than other types of HHV8-positive lymphoproliferative disorders.

Individuals with immunodeficiency are not at increased risk for intravascular large B-cell lymphoma, and HHV8-positive intravascular large B-cell lymphoma has not been reported previously. Our Case 2 shares many clinical and histologic features with those of other cases of intravascular large B-cell lymphoma. It typically affects middle-aged to older adults who have acute to subacute onset of symptoms related to vascular obstruction in a wide variety of extranodal sites, often accompanied by fever. ${ }^{26-28}$ The protean nature of the symptoms and the lack of discrete lesions often lead to a delay in diagnosis; as was true of our patient, the diagnosis is sometimes not established until autopsy. Histologic features were similar to those of other cases of intravascular large B-cell lymphoma, and it was the absence of CD20 that was unusual and prompted further immunophenotyping that disclosed the presence of HHV8. This patient had effusions in multiple body cavities at autopsy, raising the question of primary effusion lymphoma, but the effusions were not conspicuous at presentation and atypical lymphoid cells were not found along any of the mesothelial lined surfaces examined. In addition, primary effusion lymphoma usually involves only one body cavity and contains EBV in addition to HHV8, ${ }^{12}$ in contrast to our case.

One small lymph node in our Case 2 showed sinusoidal involvement. HHV8-positive lymphomas involving lymph nodes may have a partial or exclusive pattern of sinusoidal infiltration. ${ }^{29,30}$ This pattern may occur in the 'solid lymphomas' with or without lymphomatous effusions. ${ }^{29,30}$ Our previously reported case of HHV8-positive, EBVpositive plasmablastic microlymphoma progressed to frank lymphoma, and at autopsy, a sinusoidal distribution of tumor cells was found in some lymph nodes. ${ }^{23}$ The sinusoidal distribution, particularly when neoplastic cells are cytologically anaplastic and CD30 positive, may cause these lymphomas to mimic anaplastic large-cell lymphoma. ${ }^{31}$

In summary, we describe two new patterns of HHV8 involvement in lymphoproliferative disease: an intravascular large B-cell lymphoma in an HIVpositive patient and a large B-cell lymphoma bearing histologic resemblance to classical Hodgkin's lymphoma, occurring in an immunocompetent male. Finding these two distinctive cases of HHV8associated lymphoma suggests that the spectrum of HHV8-associated disease may be broader than is currently recognized.

\section{Acknowledgement}

We are grateful to Dr Don DeStephano and Dr Joel Stone of St Vincent's Hospital, Jacksonville, FL, for providing clinical information for Case 1 and to Dr Kenneth P Abriola, MD of Manchester Memorial Hospital, Manchester, CT, for providing clinical information for Case 2.

\section{Disclosure/conflict of interest}

The authors report no conflict of interest.

\section{References}

1 Chang Y, Cesarman E, Pessin MS, et al. Identification of herpes virus-like DNA sequences in AIDS-associated Kaposi's sarcoma. Science 1994;266:1865-1869. 
2 Cesarman E, Chang Y, Moore PS, et al. Kaposi's sarcoma-associated herpes virus-like DNA sequences in AIDS-related body-cavity-based lymphomas. N Engl J Med 1995;332:1186-1191.

3 Soulier J, Grollet L, Oksenhendler E, et al. Kaposi's sarcoma-associated herpesvirus-like DNA sequences in multicentric Castleman's disease. Blood 1995;84: 1276-1280.

4 Dupin N, Diss T, Kellam P, et al. HHV-8 is associated with a plasmablastic variant of Castleman disease that is linked to HHV-8-positive plasmablastic lymphoma. Blood 2000;95:1406-1412.

$5 \mathrm{Du}$ M-Q, Diss T, Liu H, et al. KSHV- and EBVassociated germinotropic lymphoproliferative disorder. Blood 2002;100:3415-3418.

$6 \mathrm{Du}$ M-Q, Liu H, Diss T, et al. Kaposi sarcomaassociated herpesvirus infects monotypic (IgMlambda) but polyclonal naive B cells in Castleman disease and associated lymphoproliferative disorders. Blood 2001; 97:2130-2136.

7 Cesarman E, Knowles D. Kaposi’s sarcoma-associated herpesvirus: a lymphotropic human herpesvirus associated with Kaposi's sarcoma, primary effusion lymphoma and multicentric Castleman's disease. Semin Diagn Pathol 1997;14:54-66.

8 Chadburn A, Hyjek E, Mathew S, et al. KSHV-positive solid lymphomas represent an extra-cavitary variant of primary effusion lymphoma. Am J Surg Pathol 2004; 28:1401-1416.

9 Gaidano G, Capello D, Cilia AM, et al. Genetic characterization of HHV-8/KSHV-positive primary effusion lymphoma reveals frequent mutations of BCL6: implications for disease pathogenesis and histogenesis. Genes Chromosomes Cancer 1999;24:16-23.

10 Hamoudi R, Diss TC, Oksenhendler E, et al. Distinct cellular origins of primary effusion lymphoma with and without EBV infection. Leuk Res 2004;28:333-338.

11 Carbone A, Gloghini A, Cozzi MR, et al. Expression of MUM1/IRF4 selectively clusters with primary effusion lymphoma among lymphomatous effusions: implications for disease histogenesis and pathogenesis. Br J Haematol 2000;111:247-257.

12 Said J, Cesarman E. Primary effusion lymphoma. In: Swerdlow S, Campo E, Harris $\mathrm{N}$, et al. (eds). WHO Classification. Tumours of Haematopoietic and Lymphoid Tissues, 4th edn. IARC: Lyon, 2008, pp 260-261.

13 Klein U, Gloghini A, Gaidano G, et al. Gene expression profile analysis of AIDS-related primary effusion lymphoma (PEL) suggests a plasmablastic derivation and identifies PEL-specific transcripts. Blood 2003;101:4115-4121.

14 Jenner RG, Boshoff C. The molecular pathology of Kaposi's sarcoma-associated herpesvirus. Biochim Biophys Acta 2002;1602:1-22.

15 Chen YB, Rahemtullah A, Hochberg E. Primary effusion lymphoma. Oncologist 2007;12:569-576.

16 Isaacson P, Campo E, Harris N. Large B-cell lymphoma arising in HHV8-associated multicentric Castleman's disease. In: Swerdlow S, Campo E, Harris N, et al. (eds). WHO Classification. Tumours of Haematopoietic and Lymphoid Tissues, 4th edn. IARC: Lyon, 2008, pp 258-259.
17 Jones D, Ballestas ME, Kaye KM, et al. Primary-effusion lymphoma and Kaposi's sarcoma in a cardiac-transplant recipient. N Engl J Med 1998;339:444-449.

18 Ferry J, Harris N. Atlas of Lymphoid Hyperplasia and Lymphoma, 1st edn. W.B. Saunders: Philadelphia, 1997, 271pp.

19 Said JW, Tasaka T, Takeuchi S, et al. Primary effusion lymphoma in women: report of two cases of Kaposi's sarcoma herpes virus-associated effusion-based lymphoma in human immunodeficiency virus-negative women. Blood 1996;88:3124-3128.

20 Carbone A, Gloghini A, Vaccher E, et al. Kaposi's sarcoma-associated herpesvirus/human herpesvirus type 8-positive solid lymphomas: a tissue-based variant of primary effusion lymphoma. J Mol Diagn 2005;7:17-27.

21 DePond W, Said J, Tasaka T, et al. Kaposi's sarcomaassociated herpesvirus and human herpesvirus 8 (KSHV/HHV8) -associated lymphoma of the bowel: Report of two cases in HIV-positive men with secondary effusion lymphomas. Am J Surg Pathol 1997;21: 719-724.

22 Deloose ST, Smit LA, Pals FT, et al. High incidence of Kaposi sarcoma-associated herpesvirus infection in HIV-related solid immunoblastic/plasmablastic diffuse large B-cell lymphoma. Leukemia 2005;19:851-855.

23 Seliem RM, Griffith RC, Harris NL, et al. HHV-8+, $\mathrm{EBV}+$ multicentric plasmablastic microlymphoma in an HIV+ Man: the spectrum of HHV-8+ lymphoproliferative disorders expands. Am J Surg Pathol 2007; 31:1439-1445.

24 Abdel-Reheim FA, Koss W, Rappaport ES, et al. Coexistence of Hodgkin's disease and giant lymph node hyperplasia of the plasma-cell type (Castleman's disease). Arch Pathol Lab Med 1996;120:91-96.

25 Carbone A. KSHV/HHV-8 associated Kaposi's sarcoma in lymph nodes concurrent with Epstein-Barr virus associated Hodgkin lymphoma. J Clin Pathol 2005;58: 626-628.

26 Ferry JA, Harris NL, Picker LJ, et al. Intravascular lymphomatosis (malignant angioendotheliomatosis). A B-cell neoplasm expressing surface homing receptors. Mod Pathol 1988;1:444-452.

27 Ponzoni M, Arrigoni G, Gould VE, et al. Lack of CD 29 (beta1 integrin) and CD 54 (ICAM-1) adhesion molecules in intravascular lymphomatosis. Hum Pathol 2000;31:220-226.

28 Zuckerman D, Seliem R, Hochberg E. Intravascular lymphoma: the oncologist's 'great imitator'. Oncologist 2006;11:496-502.

29 Ariad S, Benharroch D, Lupu L, et al. Early peripheral lymph node involvement of human herpesvirus 8-associated, body cavity-based lymphoma in a human immunodeficiency virus-negative patient. Arch Pathol Lab Med 2000;124:753-755.

30 Carbone A, Gloghini A, Vaccher E, et al. KSHV/HHV-8 associated lymph node based lymphomas in HIV seronegative subjects. Report of two cases with anaplastic large cell morphology and plasmablastic immunophenotype. J Clin Pathol 2005;58:1039-1045.

31 Huang Q, Chang KL, Gaal KK, et al. KSHV/HHV8associated lymphoma simulating anaplastic large cell lymphoma. Am J Surg Pathol 2004;28:693-697. 